\title{
Penapisan Bakteri Penghambat Fusarium yang Diisolasi dari Cairan Kantung Semar (Nepenthes sp.)
}

\section{(Screening for Fusarium Inhibiting Bacteria Isolated from Monkey Cup (Nepenthes sp.) Fluid)}

\author{
Siti Meliah ${ }^{1 *}$, Annisa Wahyu Hardiyanti ${ }^{2}$, Ni'ma Haida $^{2}$, Gita Azizah Putri ${ }^{3}$, Erny Qurotul Ainy ${ }^{2}$
}

(Diterima September 2019/Disetujui Agustus 2020)

\begin{abstract}
ABSTRAK
Cendawan dari marga Fusarium sp. merupakan patogen pada banyak tanaman budi daya. Bakteri yang diisolasi dari cairan kantung semar (Nepenthes sp.) memiliki kemampuan dalam menghasilkan enzim hidrolisis, seperti kitinase yang dapat dimanfaatkan untuk menghambat pertumbuhan miselia cendawan patogen. Penelitian ini bertujuan mengisolasi bakteri dari cairan tanaman kantung semar, menguji kemampuannya dalam menghasilkan enzim protease, kitinase, dan selulase, serta kemampuannya menghambat pertumbuhan Fusarium. Bakteri diisolasi dengan metode pengenceran berseri pada media Reasoner's 2A agar. Aktivitas enzimatis isolat bakteri ditentukan dengan menumbuhkan bakteri tersebut pada media uji yang mengandung protein kasein, kitin, dan selulosa, sedangkan aktivitas antifungi ditentukan dengan metode konfrontasi langsung antara isolat bakteri dengan cendawan patogen pada media Malt Ekstrak Agar. Identifikasi secara molekuler bakteri dengan aktivitas antifungi dilakukan melalui analisis urutan basa nukleotida gen 16S rRNA. Proses isolasi bakteri dari cairan kantung semar menghasilkan 99 isolat bakteri yang memiliki kemampuan untuk memproduksi enzim, baik protease, kitinase, dan/atau selulase. Sebanyak 37 isolat dari bakteri tersebut dapat memproduksi setidaknya dua macam enzim hidrolisis. Uji antifungi terhadap bakteri tersebut menunjukkan sebanyak 25 isolat memiliki kemampuan dalam menghambat pertumbuhan Fusarium sp.. Berdasarkan hasil analisis urutan basa nukleotida gen 16S rRNA diketahui bahwa isolat tersebut memiliki kekerabatan dengan tiga jenis Burkholderia, yaitu B. arboris, B. contaminans, dan $B$. rijonensis.
\end{abstract}

Kata kunci: antifungi, Burkholderia, kitinase, Nepenthes, protease, selulase

\section{ABSTRACT}

The genus Fusarium sp. is a pathogenic fungal for many cultivated plants. The bacteria isolated from monkey cup (Nepenthes sp.) fluid possess the ability to produce hydrolytic enzyme, such as chitinase which can be utilized to inhibit the growth of mycelia of pathogenic fungi. The aims of this study are to isolate bacteria from monkey cup liquid, to test their abilities to produce protease, chitinase, and cellulase, as well as their abilities to inhibit Fusarium. The bacteria were isolated using serial dilution method on Reasoner's $2 \mathrm{~A}$ agar medium. Enzymatic activities of bacterial isolates were determined by inoculating them on tested medium supplemented with casein protein, chitin, and cellulose, whereas their antifungal activities were assayed using a direct confrontation method between tested bacterial isolates and pathogenic fungal on Malt Extract Agar medium. Molecular identification of bacteria with antifungal activity was performed by analyzing the 16S rRNA gene sequences. Isolation process of bacteria from monkey cup fluid resulted in 99 bacterial isolates with the ability to produce either protease, chitinase, and/or cellulose enzymes. A total of $\mathbf{3 7}$ bacterial isolates were capable of producing at least two hydrolytic enzymes. Antifungal assay of those bacteria showed that as many as 25 isolates have the ability to inhibit the growth of Fusarium sp. Based on the analysis of 16S rRNA gene sequences revealed that those isolates were closely related to three Burkholderia species, namely B. arboris, B. contaminans, and B. rijonensis.

Keywords: antifungal, Burkholderia, chitinase, cellulase $N$, epenthes, protease

1 Pusat Penelitian Biologi, Lembaga IImu Pengetahuan Indonesia, Jl. Raya Jakarta-Bogor No. Km.46, Cibinong, Bogor, Jawa Barat 16911

2 Departemen Biologi, Universitas Islam Negeri Sunan Kalijaga, Jl. Laksda Adisucipto, Papringan, Caturtunggal, Depok, Sleman, Daerah Istimewa Yogyakarta 55281

3 Program Studi Teknik Industri, Universitas Pancasila, J. Raya Lenteng Agung No. 56-80, Srengseng Sawah, Jakarta, Daerah Khusus Ibukota Jakarta 12640

*Penulis Korespondensi: E-mail: siti.meliah@lipi.go.id

\section{PENDAHULUAN}

Fusarium sp. merupakan cendawan tular tanah yang menyebabkan penyakit pada banyak tanaman budi daya. Beberapa jenis Fusarium yang tergolong patogen tanaman di antaranya adalah $F$. graminearum yang menyerang tanaman gandum (Gilbert \& Fernando 2004) serta $F$. oxysporum f.sp. cubense (Ploetz 2006), F. solani (Sari et al. 2018), dan F. odoratissimum (Maryani et al. 2019) yang menyerang 
tanaman pisang. Cendawan patogen tersebut mengakibatkan penurunan kualitas dan kuantitas produk tanaman yang terinfeksi. F. oxysporum f.sp. lycopersici yang menyerang tanaman tomat, diketahui dapat menurunkan produksi buah tomat hingga $60-70 \%$ (Srinivas et al. 2019). Tidak hanya menyebabkan kerugian secara ekonomi, beberapa Fusarium menghasilkan mikotoksin yang berbahaya bagi manusia dan hewan yang mengonsumsi produk tanaman tersebut, seperti trikotesena, fumonisin, moniliformin, dan fusarin (Dinolfo et al. 2017). Trikotesena diketahui dapat menyebabkan muntah, dermatitis kulit, dan lesi hemorargik (McCormick et al. 2011). Adhikari et al. (2017) juga melaporkan kelompok mikotoksin tersebut menyebabkan penurunkan glukosa plasma, jumlah sel darah, dan bobot badan pada hewan.

Upaya pengendalian Fusarium sp. telah banyak dilakukan, mulai dari perbaikan pengelolaan tanah, penggunaan fungisida, hingga pemanfaatan agens pengendali hayati atau biokontrol. Keberadaan transposon pada sejumlah cendawan patogen, termasuk Fusarium, juga diketahui menambah tingkat plastisitas dan adaptabilitas cendawan tersebut (Santana \& Queiroz 2015) sehingga sulit dikendalikan. Sejumlah studi mengenai pemanfaatan mikroorganisme lain untuk mengendalikan Fusarium patogen telah dilakukan, di antaranya menggunakan Pseudomonas untuk mengendalikan Fusarium penyebab busuk akar pada tomat (Lemanceau \& Alabouvette 1991) dan Bacillus subtilis untuk mengendalikan layu Fusarium pada pisang (Sun et al. 2011; Bubici et al. 2019). Penggunaan agens pengendali hayati dalam menangani patogen tanaman dianggap sebagai upaya yang cukup efektif dan ramah lingkungan. Penemuan mikroorganisme penghambat Fusarium tersebut dari berbagai sumber lain diperlukan untuk memperkaya informasi dan memberikan alternatif dalam pengembangan produk biokontrol, salah satunya dengan memanfaatkan bakteri-bakteri pada cairan tanaman kantung semar (Nepenthes sp.).

Nepenthes sp. tergolong tanaman karnivora yang memiliki daun khusus berbentuk kantung yang berisi cairan untuk menjerat mangsa, berupa hewan invertebrata yang selanjutnya dicerna untuk mendapatkan nutrisi, terutama nitrogen. Kelompok tanaman ini dapat ditemukan pada lahan terbuka yang mendapat sinar matahari cukup, kecuali untuk jenis $N$. ampullaria yang lebih umum ditemukan pada hutan dengan kanopi tertutup (Moran et al. 2003). Bagian tanaman dan cairan dalam kantung semar Nepenthes sp. Merupakan habitat bagi mikroorganisme penghasil asam dan enzim yang berperan dalam mencerna serangga yang terperangkap di dalamnya. Beberapa bakteri yang diisolasi dari cairan kantung semar diketahui memiliki aktivitas enzimatis, seperti kitinolitik, proteolitik, amilolitik, selulolitik, dan xianolitik (Chan et al. 2016). Kemampuan bakteri penghasil enzim tersebut dapat dimanfaatkan untuk mengendalikan pertumbuhan cendawan patogen yang dinding selnya tersusun atas kitin, protein, dan selulosa. Oleh sebab itu, penelitian ini bertujuan untuk melakukan penapisan terhadap bakteri yang diisolasi dari cairan kantung semar (Nepenthes sp.) yang mampu menghambat pertumbuhan Fusarium penyebab penyakit pada tanaman.

\section{METODE PENELITIAN}

Sampel yang digunakan dalam penelitian ini berupa cairan dalam tanaman Kantung Semar (Nepenthes sp.) yang dikoleksi dari Gunung Betina, Karimun Besar, Kepulauan Riau pada April 2017. Seluruh cairan dalam kantung semar mengandung berbagai serangga mati ketika diambil dari lapang. Rincian sampel yang digunakan disajikan pada Tabel 1. Sebanyak tiga galur Fusarium, yakni $F$. solani InaCC F76, F. oxysporum $\mathrm{F} 78$, dan $F$. odoratissium InaCC F988 digunakan dalam pengujian antifungi.

\section{Isolasi Bakteri dari Cairan Kantung Semar}

Sampel berupa tanaman Kantung Semar dari lapang dimasukkan ke dalam kantung plastik untuk keperluan identifikasi, sedangkan cairan dalam Kantung Semar yang mengandung serangga dimasukkan ke dalam tabung steril. Cairan tersebut langsung digoreskan pada media Reasoner's 2A agar (R2A, Oxoid) (Reasoner \& Geldreich 1985) menggunakan loop steril dalam waktu kurang dari 12 jam. Proses isolasi awal ini dilakukan dalam clean bench portable dan kemudian diinkubasi pada suhu ruang $\left( \pm 25^{\circ} \mathrm{C}\right)$. Cawan agar tersebut dipindahkan ke laboratorium di InaCC untuk selanjutnya dilakukan inkubasi kembali pada suhu ruang hingga total lamanya waktu inkubasi adalah sebulan. Sel bakteri yang telah tumbuh pada media padat tersebut selanjutnya dikerok dan diencerkan secara serial hingga pengenceran $10^{-5}$ menggunakan larutan $\mathrm{NaCl} 0,85 \%$. Suspensi bakteri yang telah diencerkan kemudian disebar di atas media R2A dan diinkubasi pada suhu $30^{\circ} \mathrm{C}$ selama dua hari. Koloni bakteri yang muncul dimurnikan dengan metode kuadran. Isolat bakteri yang telah murni tersebut

Tabel 1 Sampel dari Gunung Betina, Karimun Besar, Kepulauan Riau yang digunakan dalam penelitian

\begin{tabular}{|c|c|c|c|}
\hline Sampel & Nama tanaman & Ketinggian (mdpl) & pH cairan \\
\hline KR06 & Nepenthes gracilis & 38 & 2 \\
\hline KR07 & Nepenthes gracilis & 42 & 2 \\
\hline KR15 & Nepenthes ampullaria & 47 & 5 \\
\hline KR16 & Nepenthes raflesiana & 47 & 5 \\
\hline KR17 & Nepenthes gracilis & 32 & 3 \\
\hline
\end{tabular}


selanjutnya dipreservasi menggunakan larutan gliserol $10 \%$ dan disimpan dalam lemari pembeku pada suhu $80^{\circ} \mathrm{C}$.

\section{Uji Enzim Hidrolisis}

Isolat bakteri yang diperoleh selanjutnya diuji kemampuannya dalam menghasilkan enzim hidrolisis, yakni protease, kitinase, dan selulase dengan menggoreskan sel bakteri tersebut sepanjang $1 \mathrm{~cm}$ pada media uji. Bakteri uji ditumbuhkan pada media lapis ganda untuk uji protease. Lapisan bawah media tersebut merupakan campuran glukosa $1 \mathrm{~g}$, ekstrak khamir 2,5 g, dan agar-agar $20 \mathrm{~g}$ dalam $1 \mathrm{~L}$ akuades, sedangkan lapisan atas merupakan media yang sama dengan tambahan 1\% kasein (Kiran et al. 2015). Untuk uji produksi kitinase, bakteri ditumbuhkan pada media garam mineral dengan penambahan koloid kitin menurut Amini et al. (2016) dengan modifikasi. Komposisi media terdiri atas $\mathrm{K}_{2} \mathrm{HPO}_{4} 0.7 \mathrm{~g}, \mathrm{KH}_{2} \mathrm{PO}_{4}$ $0.3 \mathrm{~g}, \mathrm{MgSO}_{4} .5 \mathrm{H}_{2} \mathrm{O} 0.5 \mathrm{~g}, \mathrm{FeSO}_{4} .7 \mathrm{H}_{2} \mathrm{O} 0.08 \mathrm{~g}, \mathrm{ZnSO}_{4}$ $0.001 \mathrm{~g}, \mathrm{MnCl}_{2} 0,001 \mathrm{~g}$, agar-agar $20 \mathrm{~g}$, dan koloid kitin $2 \%$ dalam $1 \mathrm{~L}$ akuades. Untuk uji produksi selulase, bakteri dtumbuhkan pada media garam mineral dengan komposisi $\mathrm{KH}_{2} \mathrm{PO}_{4} 2 \mathrm{~g},\left(\mathrm{NH}_{4}\right)_{2} \mathrm{SO}_{4} 1,4 \mathrm{~g}$, $\mathrm{MgSO}_{4} .5 \mathrm{H}_{2} \mathrm{O} 0,3 \mathrm{~g}, \mathrm{CaCl}_{2} 0,3 \mathrm{~g}$, yeast extract $0,4 \mathrm{~g}$. $\mathrm{FeSO}_{4} .7 \mathrm{H}_{2} \mathrm{O} 0,005 \mathrm{~g}, \mathrm{MnSO}_{4} 0,0016 \mathrm{~g}, \mathrm{ZnCl}_{2}$ 0,0017 $\mathrm{g}, \mathrm{CoCl}_{2}$ 0,002 g, carboxymethyl cellulose-Na $5 \mathrm{~g}$, dan agar-agar $15 \mathrm{~g}$ dalam $1 \mathrm{~L}$ akuades dengan $\mathrm{pH} 5$ (Liang et al. 2014). Bakteri pada masing-masing media uji tersebut diinkubasi pada suhu ruang selama 2 hari. Setelah inkubasi, cawan uji selulase diwarnai dengan larutan Congo red 0,1\% dan diinkubasi kembali selama 10 menit. Pembilasan pewarna Congo red dilakukan menggunakan larutan $\mathrm{NaCl} 1 \mathrm{M}$. Pengujian ini dilakukan sebanyak dua kali. Semua isolat yang mengasilkan zona bening pada masing-masing media uji, dinyatakan menghasilkan aktivitas enzim hidrolisis.

Uji Antagonis Bakteri terhadap Galur Fusarium sp.

Uji antagonis antara isolat bakteri dengan galur Fusarium dilakukan pada media Malt Extract Agar (MEA, Oxoid). Isolat bakteri terpilih yang menghasilkan setidaknya dua jenis enzim hidrolisis ditumbuhkan secara bersamaan dengan masing-masing galur Fusarium dalam cawan agar yang sama dengan jarak antarbakteri dengan Fusarium sebesar $1,5 \mathrm{~cm}$. Sebanyak empat isolat bakteri dapat diuji pada cawan yang sama secara bersamaan. Inkubasi dilakukan pada suhu $30^{\circ} \mathrm{C}$. Pengamatan atas kemampuan bakteri menghambat pertumbuhan Fusarium dilakukan pada hari ke-7. Uji antagonis tersebut dilakukan dengan dua ulangan.

\section{Identifikasi Molekuler Bakteri Penghasil Anti- Fusarium}

Identifikasi molekuler dilakukan berdasarkan analisis urutan basa pada gen 16S rRNA. DNA genom bakteri diekstrak melalui metode pemanasan (boiling). Sel yang telah dilarutkan dalam $20 \mu \mathrm{L}$ air bebas nuklease dipanaskan dalam mesin heat-block pada suhu $98^{\circ} \mathrm{C}$ selama 10 menit (Meliah et al. 2020). Sel tersebut kemudian disentrifugasi secara singkat dan selanjutnya digunakan sebagai cetakan DNA untuk proses Polymerase Chain Reaction (PCR). Sepasang primer universal yang terdiri atas primer forward 27F 5'-AGAGTTTGATCCTGGCTCAG-3') dan primer reverse 1492R (5'-GGTTACCTTGTTACGACTT-3') (Lane 1991) digunakan untuk mengamplifikasi gen 16S rRNA. Komposisi PCR untuk tiap reaksi terdiri atas GoTaq DNA polymerase $12,5 \mu \mathrm{L}$, primer $27 \mathrm{~F} 1 \mu \mathrm{L}$, primer 1492R $1 \mu \mathrm{L}$, dimethyl sulfoxide (DMSO) $0,5 \mu \mathrm{L}$, dan cetakan DNA $1 \mu \mathrm{L}$ dengan total volume sebanyak $25 \mu \mathrm{L}$. Kondisi reaksi PCR terdiri atas tahap pradenaturasi pada suhu $94^{\circ} \mathrm{C}$ selama 90 detik, denaturasi $94^{\circ} \mathrm{C}$ selama 30 detik, penempelan $50^{\circ} \mathrm{C}$ selama 30 detik, pemanjangan $72^{\circ} \mathrm{C}$ selama 90 detik yang dilanjutkan dengan tahap pemanjangan akhir pada suhu $72^{\circ} \mathrm{C}$ selama 10 menit. Siklus PCR yang dilakukan sebanyak 35 siklus. Produk PCR dianalisis melalui elektroforesis pada gel agarosa $1 \%$. Produk PCR tersebut kemudian diurutkan basa nukleotidanya menggunakan $\mathrm{ABI} 3730 \mathrm{xl}$ DNA Analyzer oleh Macrogen, Inc (Korea Selatan).

Urutan basa gen 16S rRNA dianalisis menggunakan program BioEdit (Hall 1999). Urutan basa hasil analisis disejajarkan dengan urutan basa lainnya pada server EzTaxon (Yoon et al. 2017). Data fasta urutan basa nukleotida isolat bakteri dengan urutan basa nukleotida strain tipe selanjutnya disejajarkan menggunakan program MUSCLE (Edgar 2004) untuk menyusun pohon filogenetik. Penyusunan pohon filogenetik menggunakan metode Neighbor Joining (Saitou \& Nei 1987) dengan model Kimura 2-parameter (Kimura 1980) sebanyak 1000 kali pengulangan yang dilakukan melalui program MEGA $X$ (Kumar et al. 2018).

\section{HASIL DAN PEMBAHASAN}

\section{Isolasi Bakteri dari Cairan Kantung Semar}

Total sebanyak 99 isolat bakteri berhasil diisolasi dari cairan 5 Kantung Semar asal Pulau Karimun, Kepulauan Riau. Proses isolasi menggunakan media R2A yang nutrisinya relatif rendah untuk memperbesar peluang didapatkannya bakteri-bakteri yang pertumbuhannya lambat. Secara morfologi, sebagian besar bakteri yang diperoleh memiliki koloni berbentuk bulat, tepi rata, dan berwarna putih atau kekuningan. Beberapa bakteri memproduksi lendir yang cukup banyak.

Cairan dalam kantung pada tanaman Nepenthes sp. diketahui berperan dalam proses mencerna mangsa berupa serangga karena kandungan enzim hidrolisis yang dimilikinya. Salah satu enzim dari tanaman kantung semar yang sudah dikarakterisasi dengan baik adalah nepentesin (Takahashi et al. 2005). Cairan kantung semar memiliki pH yang rendah sehingga bersifat asam. Kadar asam yang tinggi pada cairan kantung semar menghasilkan lingkungan yang 
ekstrem bagi mikroorganisme. Cairan tersebut juga diketahui mengandung protein dengan aktivitas antimikroorganisme (Mithöfer 2011). Meskipun demikian, sejumlah komunitas bakteri, seperti kelompok Alfaproteobakteria, dilaporkan mampu hidup dengan baik di dalamnya (Chou et al. 2014).

Selain cairan dalam kantung, bagian lain dari tanaman kantung semar juga dilaporkan merupakan habitat bagi sejumlah bakteri yang bersifat endofit (Bhore et al. 2013). Adanya bakteri-bakteri tersebut diduga membantu tanaman dalam mencerna serangga. Keragaman dan kelimpahan bakteri tersebut dipengaruhi oleh pH cairan dalam kantung (Kanokratana et al. 2016) dan fase pertumbuhan tanaman. Fase pertumbuhan pada tanaman Nepenthes sp. menyebabkan perubahan pada komposisi cairan (Buch et al. 2013). Sampel berupa cairan kantung semar yang digunakan dalam penelitian ini berasal dari kantung semar yang sudah terbuka sepenuhnya dan mengandung serangga, terutama semut.

\section{Uji Enzim Hidrolisis}

Berdasarkan uji kemampuan isolat bakteri asal cairan kantung semar dalam menghasilkan enzim hidrolisis diketahui sebanyak 48 isolat mampu menghidrolisis protein kasein, 10 isolat mampu menghidrolisis kitin, dan sebanyak 77 isolat mampu menghidrolisis selulosa yang ditandai dengan terbentuknya zona bening pada masing-masing media uji. Sebanyak 37 isolat atau $37 \%$ dari total bakteri yang diuji dapat menghasilkan setidaknya dua enzim (Tabel 2). Di antara bakteri tersebut, sebanyak 18 isolat diisolasi dari $N$. gracilis, sebanyak 16 isolat dari $N$. ampullaria, dan sebanyak 3 isolat diisolasi dari $N$. raflesiana. Bakteri yang menghasilkan lebih dari satu jenis enzim kemudian digunakan dalam uji antifungi dengan beberapa Fusarium.

Enzim yang dihasilkan oleh bakteri dari cairan Kantung Semar tidak terbatas pada ketiga enzim yang diuji dalam penelitian ini. Studi metagenomik pada komunitas bakteri pada kantung semar juga berhasil mendeteksi adanya gen yang menyandi lipase sehingga diduga bakteri pada cairan kantung semar tersebut mampu memproduksi enzim lipase pada kondisi asam (Morohoshi et al. 2011). Kontribusi enzim-enzim hidrolisis tersebut dalam mendegradasi eksoskeleton serangga sangat penting, terutama enzim kitinase karena kitin merupakan komponen terbesar penyusun eksoskeleton serangga.

Adanya kemiripan antara komponen penyusun eksoskeleton serangga dengan penyusun dinding sel sebagian besar cendawan menjadi dasar dilakukannya uji kemampuan bakteri asal cairan kantung semar melawan cendawan patogen tanaman. Aktivitas enzimatis yang dihasilkan oleh mikroorganisme banyak dimanfaatkan untuk melawan cendawan patogen tanaman, seperti enzim kitinase yang diproduksi oleh Serratia plymuthica untuk melawan Botrytis cinerea (Frankowski et al. 2001). Keterlibatan enzim lain yang dihasilkan mikroorganisme, yaitu $\beta$-1,3-glukanase juga mendukung aktivitas antifungi terhadap cendawan $F$. oxysporum f.sp. cucumerinum oleh Paenibacillus dan Streptomyces (Jeun et al. 2004).

Terkait dengan sampel yang digunakan dalam penelitian ini, sejumlah penelitian melaporkan bahwa cairan kantung semar memiliki kemampuan antifungi terhadap sejumlah khamir, seperti Candida albicans, C. glabrata, C. Krusei, dan C. tropicalis (Yolanda et al. 2015) dan cendawan, seperti Aspergillus sp. Kemampuan tersebut disebabkan oleh kandungan droseron, 5-O-metil droseron, dan naftokuinon yang dapat menghambat pertumbuhan mikroorganisme tersebut dalam konsentrasi rendah (Eilenberg et al. 2010). Secara spesifik, penelitian lain mengungkap potensi bakteri yang diisolasi dari cairan kantung semar sebagai penghasil senyawa antibakteri, terutama Escherichia coli dan Staphylococcus aureus (Hidayat 2015). Akan tetapi, kajian mengenai peran bakteri dalam cairan kantung semar dalam mengendalikan cendawan patogen belum banyak dilakukan.

Tabel 2 Hasil uji kemampuan bakteri asal cairan Kantung Semar dalam menghasilkan enzim protease, kitinase, dan selulase

\begin{tabular}{|c|c|c|c|c|c|c|c|c|c|c|c|}
\hline \multirow{2}{*}{ Isolat } & \multicolumn{3}{|c|}{ Enzim } & \multirow{2}{*}{ Isolat } & \multicolumn{3}{|c|}{ Enzim } & \multirow{2}{*}{ Isolat } & \multicolumn{3}{|c|}{ Enzim } \\
\hline & $\mathrm{P}$ & $\mathrm{K}$ & S & & $P$ & $\mathrm{~K}$ & S & & $P$ & $\mathrm{~K}$ & $\mathrm{~S}$ \\
\hline KR06-03 & + & - & + & KR06-24 & + & - & + & KR15-15 & + & - & + \\
\hline KR06-04 & + & + & - & KR07-01 & + & - & + & KR15-16 & + & - & + \\
\hline KR06-05 & - & + & + & KR07-08 & + & - & + & KR15-17 & + & - & + \\
\hline KR06-08 & + & + & - & KR07-25 & + & - & + & KR15-19 & + & - & + \\
\hline KR06-10 & + & + & + & KR07-27 & + & - & + & KR15-20 & + & - & + \\
\hline KR06-12 & + & + & + & KR15-01 & + & - & + & KR15-22 & + & - & + \\
\hline KR06-15 & + & + & + & KR15-02 & + & + & + & KR15-23 & + & - & + \\
\hline KR06-17 & + & - & + & KR15-04 & + & - & + & KR15-24 & + & - & + \\
\hline KR06-18 & + & + & + & KR15-05 & + & - & + & KR16-05 & + & - & + \\
\hline KR06-19 & + & + & - & KR15-08 & + & - & + & KR16-16 & + & - & + \\
\hline KR06-20 & + & + & - & KR15-12 & + & - & + & KR16-26 & + & - & + \\
\hline KR06-21 & + & - & + & KR15-13 & + & - & + & & & & \\
\hline KR06-22 & + & - & + & KR15-14 & + & - & + & & & & \\
\hline
\end{tabular}


Uji Antagonis Bakteri terhadap Galur Fusarium sp.

Uji antagonis dengan konfrontasi langsung antara sel bakteri dengan sel cendawan menunjukkan sebanyak 25 isolat mampu menghambat pertumbuhan $F$. solani, sebanyak 23 isolat mampu menghambat $F$. oxysporum, dan sebanyak 16 isolat mampu menghambat $F$. odoratissimum. Di antara isolat bakteri yang diuji, sebanyak 15 isolat mampu menghambat ketiga jenis Fusarium (Tabel 3). Besarnya kemampuan bakteri dalam menghambat pertumbuhan miselia cendawan tersebut bervariasi dan secara umum, $F$. oxysporum paling mudah dihambat oleh bakteri asal cairan kantung semar karena menghasilkan diameter zona hambat yang paling besar (Gambar 1). Secara morfologi, bakteri dengan aktivitas antifungi tersebut menghasilkan lendir eksopolisakarida yang cukup banyak.

Berdasarkan hasil uji antagonis diketahui juga bahwa sebanyak 13 isolat penghasil enzim terbukti tidak memiliki aktivitas antifungi. Meskipun aktivitas enzimatis seperti kitinase dan glukanase diketahui berperan dalam menghambat pertumbuhan cendawan (Prapagdee et al. 2008), kemampuan dalam menghambat pertumbuhan cendawan tidak hanya disebabkan oleh kerja enzim. Senyawa lain yang diproduksi melalui metabolisme sekunder bakteri banyak dilapor-

Tabel 3 Kemampuan isolat bakteri asal cairan kantung semar dalam menghambat pertumbuhan Fusarium sp.

\begin{tabular}{|c|c|c|c|c|c|c|c|}
\hline \multirow[t]{2}{*}{ Isolat } & \multicolumn{3}{|c|}{ Galur Fusarium sp. } & \multirow[t]{2}{*}{ Isolat } & \multicolumn{3}{|c|}{ Galur Fusarium sp. } \\
\hline & InaCC F76 & InaCC F78 & InaCC F988 & & InaCC F76 & InaCC F78 & InaCC F988 \\
\hline KR06-03 & ++ & ++ & + & KR15-02 & - & - & - \\
\hline KR06-04 & - & - & - & KR15-04 & - & - & - \\
\hline KR06-05 & - & - & - & KR15-05 & + & +++ & - \\
\hline KR06-08 & - & - & - & KR15-08 & + & + & - \\
\hline KR06-10 & - & - & - & KR15-12 & + & - & - \\
\hline KR06-12 & - & - & - & KR15-13 & + & +++ & - \\
\hline KR06-15 & + & ++ & + & KR15-14 & + & +++ & + \\
\hline KR06-17 & ++ & ++ & ++ & KR15-15 & + & +++ & - \\
\hline KR06-18 & ++ & ++ & ++ & KR15-16 & + & +++ & - \\
\hline KR06-19 & - & - & - & KR15-17 & + & + & + \\
\hline KR06-20 & ++ & ++ & + & KR15-19 & - & - & - \\
\hline KR06-21 & + & ++ & ++ & KR15-20 & + & + & - \\
\hline KR06-22 & ++ & ++ & + & KR15-22 & + & + & + \\
\hline KR06-24 & - & - & - & KR15-23 & + & + & + \\
\hline KR07-01 & + & +++ & ++ & KR15-24 & + & + & - \\
\hline KR07-08 & + & ++++ & ++ & KR15-25 & - & - & - \\
\hline KR07-25 & + & +++ & - & KR16-05 & + & +++ & ++ \\
\hline KR07-27 & + & +++ & ++ & KR16-16 & - & - & - \\
\hline KR15-01 & + & - & + & KR16-26 & - & - & - \\
\hline
\end{tabular}

Keterangan: Tanda (+) menunjukkan bahwa isolat mampu menghambat pertumbuhan Fusarium sp. yang jumlahnya bertambah sesuai dengan pertambahan aktivitas penghambatan; tanda (-) menunjukkan isolat tidak dapat menghambat Fusarium sp.

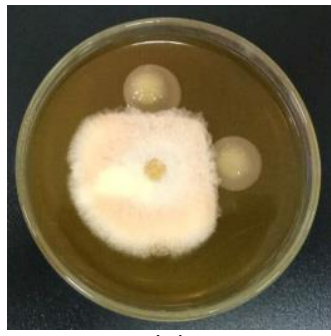

(a)

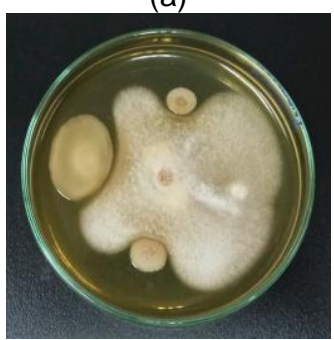

(e)

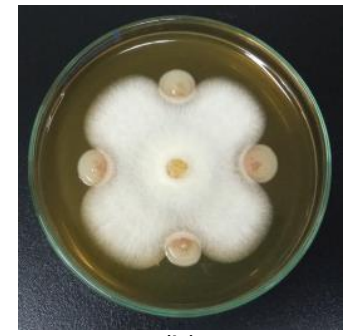

(b)

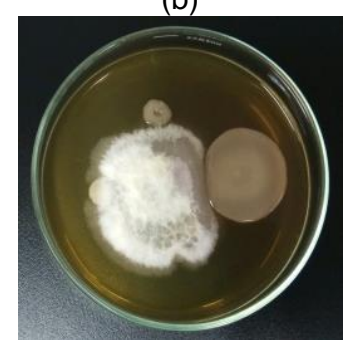

(f)

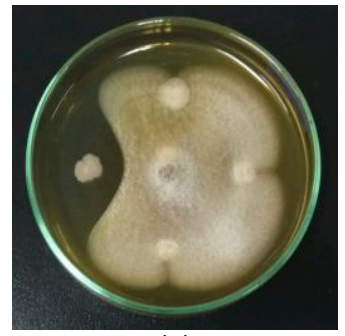

(c)

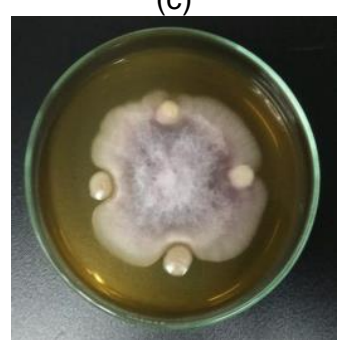

(g)

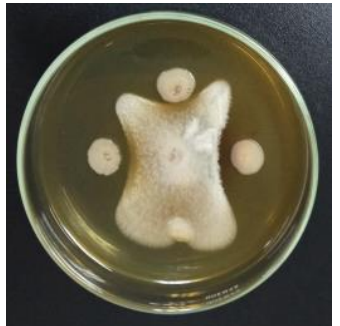

(d)

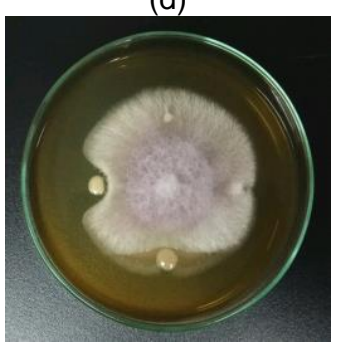

(h)

Gambar 1 Aktivitas penghambatan galur Fusarium sp. oleh bakteri; A. KR06-3 dan KR06-20; B. KR15-13, KR15-14, KR1515, dan KR15-16 terhadap F. solani InaCC F76; C. KR07-8; D. KR15-15, KR15-16, dan KR07-1; E. KR15-17, KR15-20, dan KR06-17 terhadap F. oxysporum InaCC F78; F. KR06-18; G. KR15-1 dan KR15-23; H. KR16-5 terhadap F. odoratossium InaCC F988. Galur bakteri dan cendawan ditumbuhkan pada media MEA selama 7 hari. 
kan memiliki aktivitas antifungi, di antaranya fenazin dan pirolnitrin yang diproduksi oleh bakteri Pseudomonas sp. (Park et al. 2011).

\section{Identifikasi Molekuler Bakteri Penghambat Fusarium}

Analisis urutan basa nukleotida gen 16S rRNA dengan panjang berkisar antara 1282-1381 pb dari 25 isolat bakteri dengan kemampuan menghambat pertumbuhan cendawan menunjukkan bahwa semua isolat tersebut termasuk dalam genus Burkholderia yang merupakan anggota kelas Betaproteobacteria (Gambar 2). Keberadaan Betaproteobacteria diketahui melimpah pada cairan Kantung Semar Nepenthes sp., yaitu berkisar antara $1,9-24,6 \%$ dari total sel mikroorganisme, di samping kelompok Alphaproteobacteria yang mendominasi komposisi mikroorganisme pada habitat tersebut (Takeuchi et al. 2015).
Berdasarkan posisinya dalam pohon filogenetik, sebanyak 18 isolat memiliki kekerabatan dengan $B$. arboris strain R-24201 (nomor aksesi AM747630) dengan persentase kemiripan sebesar $99 \%$, sebanyak 1 isolat memiliki kekerabatan dengan $B$. contaminans strain LMG 23361 (nomor aksesi LASD01000006) dengan persentase kemiripan sebesar $99 \%$, dan sebanyak 6 isolat memiliki kekerabatan dengan $B$. rijonensis strain A396 (nomor aksesi KF650996) dengan persentase kemiripan sebesar $99 \%$. B. arboris dapat ditemukan pada sampel lingkungan, seperti tanah dan rizosfer maupun dari sampel klinis (Vanlaera et al. 2008).

Bakteri dari genus Burkholderia banyak dilaporkan memiliki peran dalam meningkatkan pertumbuhan tanaman, terutama karena aktivitas antifungi yang dihasilkannya. Selain enzim hidrolisis, senyawa lain seperti pirolnitrin (Sultan et al. 2008), 1-metil-4-(1metiletenil)-sikloheksana (Elshafie et al. 2012),

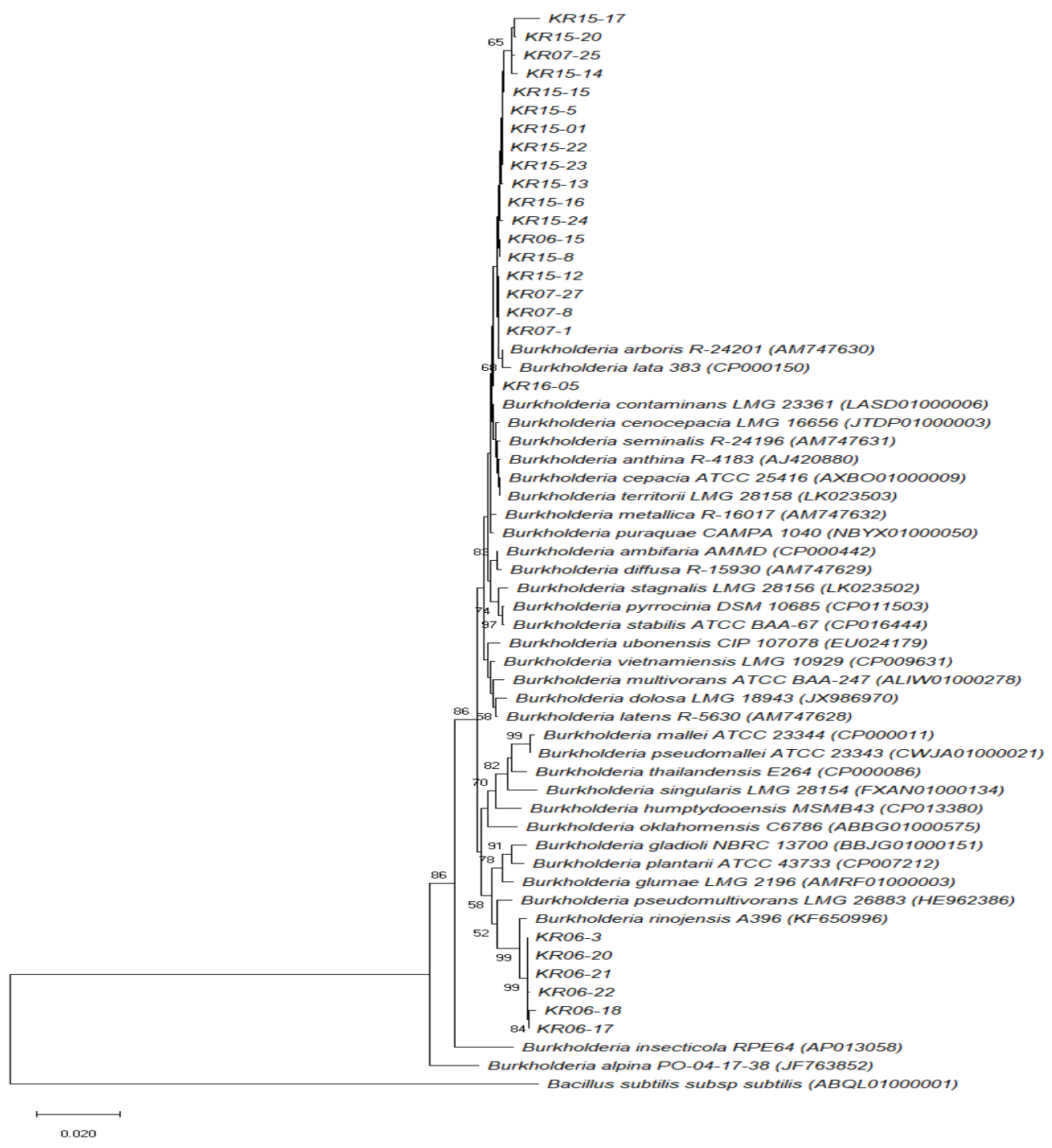

Gambar 2 Hubungan kekerabatan antara bakteri asal kantung semar yang memiliki kemampuan menghambat Fusarium dengan kelompok Burkholderia terdekat pada pohon filogenetik yang disusun menggunakan metode Neighbor Joining dengan model Kimura 2 parameter. Angka di depan nodus merupakan nilai bootstrap yang disajikan dalam persentase. Hanya nilai bootsrap lebih dari $50 \%$ yang ditampilkan. 
burkholdin (Lin et al. 2012), dan ocidiofungin (Wang et al. 2016) yang dihasilkan oleh genus tersebut diketahui mampu menghambat pertumbuhan cendawan patogen tanaman, di antaranya Rhizoctonia solani dan $F$. oxysporum. Ocidiofungin yang diproduksi oleh $B$. contaminans juga dilaporkan sangat aktif terhadap cendawan patogen Pythium spinosum dan Pythium ultimum. Senyawa tersebut menarget integritas membran dengan cara mengganggu pembentukan dinding sel dan menghambat kerja enzim cendawan yang diuji (Lu et al. 2009). Selain memiliki kemampuan menghambat pertumbuhan cendawan, dalam laporan lain disebutkan bahwa $B$. rijonensis memiliki aktivitas insektisidal dan mitisidal (Cordova-Kreylos et al. 2013).

Pemanfaatan mikroorganisme untuk mengendalikan cendawan patogen merupakan upaya yang ramah lingkungan dibandingkan dengan menggunakan senyawa kimia sintetis. Pengungkapan potensi bakteri dari berbagai habitat dan wilayah di Indonesia sebagai penghasil senyawa penghambat Fusarium diharapkan dapat memberikan alternatif dalam pengembangan agens pengendali hayati untuk patogen tanaman budi daya tersebut. Penelitian lebih lanjut perlu dilakukan untuk

\section{KESIMPULAN}

Mikroorganisme berupa bakteri telah dikoleksi dari cairan dalam kantung semar (Nepenthes sp.) sebanyak 99 isolat. Bakteri tersebut menghasilkan enzim yang dapat menghidrolisis protein, selulosa, dan kitin pada media uji. Sebanyak 37 isolat bakteri menghasilkan lebih dari satu jenis enzim dan sebanyak 25 di antaranya memiliki kemampuan dalam menghambat pertumbuhan cendawan Fusarium. Identifikasi bakteri melalui analisis urutan basa nukleotida gen 16S rRNA menunjukkan bahwa bakteri tersebut merupakan anggota genus Bukholderia. Dengan demikian, bakteri yang diisolasi dari cairan kantung semar tersebut berpotensi sebagai agens pengendali hayati cendawan patogen pada tanaman.

\section{UCAPAN TERIMA KASIH}

Penelitian ini didanai melalui program DIPA untuk Pusat Penelitian Biologi dan PKT Kebun Raya Bogor, LIPI. Ucapan terima kasih kami ucapkan kepada Ruby Setiawan, Tri Ratna Sulistiyani, dan semua anggota tim ekspedisi KR Batam-Kepulauan Riau selama kegiatan pengambilan sampel, serta Rinatu Siswi atas asistensinya selama pekerjaan di laboratorium.

\section{DAFTAR PUSTAKA}

Adhikari M, Negi B, Kaushik N, Adhikari A, Al-Khedairy AA, Kaushik NK, Choi EH. 2017. T-2 mycotoxin: toxicological effects and decontamination strategies. Oncotarget. 8(20): 33933-33952. https:// doi.org/10.18632/oncotarget.15422

Amini J, Agapoor Z, Ashengroph M. 2016. Evaluation of Streptomyces spp. against Fusarium oxysporum f. $\mathrm{sp}$. ciceris for the management of chickpea wilt. Journal of Plant Protection Research. 56(3): 257-264. https:// doi.org/10.1515/jppr-2016-0038

Bhore SJ, Komathi V, Kandasamy KI. 2013. Diversity of endophytic bacteria in medicinally important Nepenthes species. Journal of Natural Science, Biology and Medicine. 4(2): 431-434. https://doi.org/ 10.4103/0976-9668.117022

Bubici G, Kaushal M, Prigigallo MI, Gomez-Lama Cabanaz C, Mercado-Blanco J. 2019. Biological control agents against fusarium wilt of banana. Frontiers in Microbiology. 10: 1-33. https:// doi.org/10.3389/fmicb.2019.01290

Buch F, Rott M, Rottloff S, Paetz C, HIlke I, Raessler M, Mithofer A. 2013. Secreted pitfall-trap fluid of carnivorous Nepenthes plants is unsuitable for microbial growth. Annals of Botany. 111(3): 375-383. https://doi.org/10.1093/aob/mcs287

Chan XY, Hong KW, Yin WF, Chan KG. 2016. Microbiome and biocatalytic bacteria in monkey cup (Nepenthes pitcher) digestive fluid. Scientific Reports. 6(1): 1-10. https://doi.org/10.1038/ srep20016

Chou LY, Clarke CM, Dykes GA. 2014. Bacterial communities associated with the pitcher fluids of three Nepenthes (Nepenthaceae) pitcher plant species growing in the wild. Archives of Microbiology. 196(10): 709-717. https://doi.org/ 10.1007/s00203-014-1011-1

Cordova-Kreylos AL, Fernandez LE, Koivunen M, Yang A, Flor-Weiler L, Marrone PG. 2013. Isolation and characterization of Burkholderia rinojensis $\mathrm{sp}$. nov., a non-Burkholderia cepacia complex soil bacterium with insecticidal and miticidal activities. Applied and Environmental Microbiology. 79(24): 7669-7678. https://doi.org/10.1128/AEM.02365-13

Dinolfo MI, Castañares E, Stenglein SA. 2017. Fusarium-plant interaction: state of the art-a review. Plant Protection Science. 53(2): 61-70. https://doi.org/10.17221/182/2015-PPS

Edgar RC. 2004. MUSCLE: multiple sequence alignment with high accuracy and high throughput. Nucleic Acids Research. 32(5): 1792-1797. https://doi.org/10.1093/nar/gkh340

Eilenberg $\mathrm{H}$, Pnini-Cohen S, Rahamin Y, Sionov E, Segal E, Carmeli S, Zilberstein A. 2010. Induced production of antifungal naphthoquinones in the pitchers of the carnivorous plant Nepenthes khasiana. Journal of Experimental Botany. 61(3): 911-922. https://doi.org/10.1093/jxb/erp359 
Elshafie HS, Camele I, Racioppi R, Scranol L, Lacobellis NS, Bufo SA. 2012. In vitro antifungal activity of Burkholderia gladioli pv. agaricicola against some phytopathogenic fungi. International Journal of Molecular Sciences. 13(12): 16291-16302. https://doi.org/10.3390/ijms1312 16291

Frankowski J, Lorito M, Scala F, Schmid R, Berg G, Bahl H . 2001. Purification and properties of two chitinolytic enzymes of Serratia plymuthica HROC48. Archives of Microbiology. 176(6): 421-426. https://doi.org/10.1007/s002030100347

Gilbert J, Fernando WGD. 2004. Epidemiology and biological control of Gibberella zeae /Fusarium graminearum. Canadian Journal of Plant Pathology. 26(4): 464-472. https://doi.org/10.1080/0706 0660409507166

Hall TA. 1999. BIOEDIT: a user-friendly biological sequence alignment editor and analysis program for Windows 95/98/ NT. Nucleic Acids Symposium Series. 41(41): 95-98. https://doi.org/10.22202/ bc.2015.v1i1.1523

Hidayat Y. 2015. Isoalsi bakteri penghasil antibiotika dari cairan kantong semar (Nepenthes spp.) cagar alam lembah harau Sumatera Barat. Bioconcetta. 1(1): 20-31.

Jeun YC, Park KS, Kim CH, Fowler WD, Kloepper JW. 2004. Cytological observations of cucumber plants during induced resistance elicited by rhizobacteria. Biological Control. 29(1): 34-42. https://doi.org/ 10.1016/ S1049-9644(03)00082-3

Kanokratana P, Mhuanthong W, Laothanacareon T, Tangphatsornruang S, Eurwilaichitr L, Kruetreepradit T, Mayes S, Champreda V. 2016. Comparative study of bacterial communities in Nepenthes pitchers and their correlation to species and fluid acidity. Microbial Ecology. 72(2): 381-393. https://doi.org/10.1007/s00248-016-0798-5

Kimura M. 1980. A simple method for estimating evolutionary rates of base substitutions through comparative studies of nucleotide sequences. Journal of Molecular Evolution. 16(2): 112-120. https://doi.org/10.1007/BF01731581

Kiran T, Asad W, Siddiqui S, Ajaz M, Rasool SA. 2015. Industrially important hydrolytic enzyme diversity explored in stove ash bacterial isolates. Pakistan Journal of Pharmaceutical Sciences. 28(6): 2035-2040.

Kumar S, Stecher G, Li M, Knyaz C, Tamura K. 2018. MEGA X: molecular evolutionary genetics analysis across computing platforms. Molecular Biology and Evolution. 35(6): 1547-1549. https://doi.org/10. 1093/ molbev/msy096

Lane DJ. 1991. 16S/23S rRNA sequencing. Stackebrandt E, Goodfellow M, Ed. In: Nucleic acid techniques in bacterial systematics. Chinchester (UK): John Wiley and Sons Ltd. p. 115-175

Lemanceau P, Alabouvette C. 1991. Biological control of fusarium diseases by fluorescent Pseudomonas and non-pathogenic Fusarium. Crop Protection. 10(4): 279-286. https://doi.org/10.1016/02612194(91)90006-D

Liang YL, Zhang Z, Wu M, Wu Y, Feng JX. 2014. Isolation, screening, and identification of cellulolytic bacteria from natural reserves in the subtropical region of China and optimization of cellulase production by Paenibacillus terrae ME27-1. BioMed Research International. 2014: 1-13. https:// doi.org/10.1155/2014/512497

Lin Z, Falkinham III JO, Tawfik KA, Jeffs P, Bray B, Dubay G, Cox JE, Schmidt EW. 2012. Burkholdines from Burkholderia ambifaria: antifungal agents and possible virulence factors. Journal of Natural Products. 75(9): 1518-1523. https://doi.org/10. 1021/ np300108u

Lu SE, Novak J, Austin FW, Gu G, Ellis D, Kirk M, Wilson-Stanford S, Tonelli M, Smith L. 2009. Occidiofungin, a unique antifungal glycopeptide produced by a strain of Burkholderia contaminans. Biochemistry. 48(35): 8312-8321. https://doi.org/ 10.1021/bi900814c

Maryani N, Lombard L, Poerba YS, Subandiyah S, Crous PW, Kema GHJ. 2019. Phylogeny and genetic diversity of the banana fusarium wilt pathogen Fusarium oxysporum f. sp. cubense in the Indonesian centre of origin. Studies in Mycology. 92: 155-194. https://doi.org/10.1016/j.simyco. 2018.06.003

McCormick SP, Stanley AM, Stover NA, Alexander NJ. 2011. Trichothecenes: from simple to complex mycotoxins. Toxins. 3(7): 802-814. https:// doi.org/10.3390/toxins3070802

Meliah S, Kusumawati DI, Ilyas M. 2020. Preliminary study of myxobacteria as biocontrol agents for panama disease pathogen, tropical race 4 Fusarium odoratissimum. In IOP Conference Series: Earth and Environmental Science. 457(1): 012060 https://doi.org/10.1088/1755-1315/457/1/012060

Mithöfer A. 2011. Carnivorous pitcher plants: insights in an old topic. Phytochemistry. 72(13): 1678-1682. https://doi.org/10.1016/j.phytochem.2010.11.024

Moran JA, Clarke CM, Hawkins BJ. 2003. From carnivore to detritivore? Isotopic evidence for leaf litter utilization by the tropical pitcher plant Nepenthes ampullaria. International Journal of Plant Sciences. 164(4): 635-639.

Morohoshi T, Oikawa M, Sato S, Kikuchi N, Nato N, Ikeda T. 2011. Isolation and characterization of novel lipases from a metagenomic library of the microbial community in the pitcher fluid of the 
carnivorous plant Nepenthes hybrida. Journal of Bioscience and Bioengineering. 112(4): 315-320. https://doi.org/10.1016/j.jbiosc.2011.06.010

Park JY, Oh SA, Anderson AJ, Neiswender J, Kim JS, Kim YC. 2011. Production of the antifungal compounds phenazine and pyrrolnitrin from Pseudomonas chlororaphis $\mathrm{O} 6$ is differentially regulated by glucose. Letters in Applied Microbiology. 52(5): 532-537. https://doi.org/10. 1111/ j.1472-765X.2011.03036.x

Ploetz RC. 2006. Fusarium-induced diseases of tropical perennial crops fusarium wilt of banana is caused by several pathogens referred to as Fusarium oxysporum f.sp cubense. Symposium: Fusarium-Induced Diseases of Tropical Perennial Crops. 96(6): 653-656. https://doi.org/10.1094/ PHYTO-96-0653

Prapagdee B, Kuekulvong C, Mongkolsuk S. 2008. Antifungal potential of extracellular metabolites produced by Streptomyces hygroscopicus against phytopathogenic fungi. International Journal of Biological Sciences. 4(5): 330-337 https:// doi.org/10.7150/ijbs.4.330

Reasoner DJ, Geldreich EE. 1985. A new medium for the enumeration and subculture of bacteria from potable water. Applied and Environmental Microbiology. 49(1): 1-7. https://doi.org/10.1128/ AEM.49.1.1-7.1985

Saitou N, Nei M. 1987. The neighbor-joining method: a new method for reconstructing phylogenetic trees. Molecular biology and evolution. 4(4): 406-425. https://doi.org/10.1093/oxfordjournals.molbev.a040 454

Santana MF, Queiroz MV. 2015. Transposable elements in fungi: a genomic approach. Scientific Journal of Genetics and Gene Therapy. 1(1): 12-16. https://doi.org/10.17352/sjggt.000003

Sari W, Wiyono S, Nurmansyah A, Munif A, Poerwanto R. 2018. Keanekaragaman dan patogenisitas Fusarium spp. asal beberapa kultivar pisang. Jurnal Fitopatologi Indonesia. 13(6): 216-228. https:// doi.org/10.14692/jfi.13.6.216

Srinivas C, Devi DN, Murthy KN, Mohan CD, Lakshmeesha TR, Singh B, Kalagatur NK, Niranjana RR, Hashem A, Alqarawi AA, Tabassum B, Abd Allah EF, NAyaka C, Srivastava RK. 2019. Fusarium oxysporum f.sp. lycopersici causal agent of vascular wilt disease of tomato: biology to diversity-a review. Saudi Journal of Biological Sciences. 26(7): 1315-1324. https://doi.org/ 10.1016/ j.sjbs.2019.06.002
Sultan MZ, Park K, Lee SY, Park JK, Varughhese T, Moon SS. 2008. Novel oxidized derivatives of antifungal pyrrolnitrin from the bacterium Burkholderia cepacia K87. Journal of Antibiotics. 61(7): 420-425. https://doi.org/10.1038/ja.2008.58

Sun JB, Peng M, Wang YG, Zhao PJ, Xia QY. 2011. Isolation and characterization of antagonistic bacteria against fusarium wilt and induction of defense related enzymes in banana. African Journal of Microbiology Research. 5(5): 509-515.

Takahashi K, Athauda SB, Matsumoto K, Rajapakshe S, Kuribayashi M, Kojima M, Kubomura-Yoshida N, Iwamatsu A, Shiabata C, Inoue H. 2005. Nepenthesin, a unique member of a novel subfamily of aspartic proteinases: enzymatic and structural characteristics. Current Protein \& Peptide Science. 6(6): 513-525. https://doi.org/10.2174/138920 305774933259

Takeuchi Y, Chaffron S, Salcher MM, Shimizu-Inatsugi R, Kobayashi MJ, Diway B, von Mering C, Pernhaler J, Shimizu KK. 2015. Bacterial diversity and composition in the fluid of pitcher plants of the Genus Nepenthes. Systematic and Applied Microbiology. 38(5): 330-339. https://doi.org/ 10.1016/j.syapm.2015.05.006

Vanlaera E, LiPuma JJ, Baldwin A, Henry D, De Brandt E, Mahenthiralingam E, Speert D, Dowson C, Vandamme P. 2008. Burkholderia latens sp. nov., Burkholderia diffusa sp. nov., Burkholderia arboris sp. nov., Burkholderia seminalis sp. nov., and Burkholderia metallica sp. nov., novel species within the Burkholderia cepacia complex. International Journal of Systematic and Evolutionary Microbiology. 58(7): 1580-1590. https://doi.org/10. 1099/ ijs.0.65634-0

Wang XQ, Liu AX, Guerrero A, Liu J, Yu XQ, Deng P, Ma L, BAird SM, Smith L, Li XD, Lu SE. 2016. Occidiofungin is an important component responsible for the antifungal activity of Burkholderia pyrrocinia strain Lyc2. Journal of Applied Microbiology. 120(3): 607-618. https:// doi.org/10.1111/jam.13036

Yolanda H, Makashinda IM, Aprilia M, Sanjaya N, Gunawan H, Dewi R. 2015. Nepenthes rafflesiana pitcher liquid has antifungal activity against Candida spp. Mycoses. 33(2): 83-90.

Yoon SH, Ha SM, Kwon S, Lim J, Kim Y, Seo H, Chun J. 2017. Introducing EzBioCloud: a taxonomically united database of 16S rRNA gene sequences and whole-genome assemblies. International Journal of Systematic and Evolutionary Microbiology. 67(5): 1613-1617. https://doi.org/10.1099/ijsem.0.001755 